\title{
Mineral manipulation and antioxidative studies in carnation - Dianthus caryophyllus L.
}

\author{
Smita PUROHIT ${ }^{1^{*}}$ and Meghana AGARWAL ${ }^{2}$ \\ ${ }^{1}$ Department of Botany, The IIS University, Jaipur, Rajasthan, India \\ ${ }^{2}$ Department of Botany, The IIS University, Jaipur, Rajasthan, India
}

\begin{abstract}
The effect of ammonium nitrate $\left(\mathrm{NH}_{4} \mathrm{NO}_{3}\right)$ on shoot bud induction and proliferation from nodal explants of Dianthus caryophyllus L. was investigated. Shoot buds were induced on MS medium supplemented with 2.2 $\mu \mathrm{M}$ BAP and 2.7 $\mu \mathrm{M}$ NAA. The induced shoot buds were subcultured on medium with same hormonal composition for their proliferation. Both shoot bud induction and proliferation media were supplemented with different levels of $\mathrm{NH}_{4} \mathrm{NO}_{3}(0,5.15$, $\left.10.3,20.61^{*}, 41.20 \mathrm{mM}\right)$. $\mathrm{NH}_{4} \mathrm{NO}_{3}$ highly influenced the shoot bud formation and their subsequent proliferation. In the present investigation, $\mathrm{NH}_{4} \mathrm{NO}_{3}$ at one-fouth of $\mathrm{MS}$ level was found to be beneficial for controlling the hyperhydricity of regenerated shoots whereas the number of shoots was comparable to the control cultures. The MS or higher levels of $\mathrm{NH}_{4} \mathrm{NO}_{3}$ were observed to suppress healthy morphogenesis and resulted in increased hyperhydricity. The physiological disorder of hyperhydricity, commonly observed in carnation micropropagation, was also controlled with $100 \%$ efficiency by reducing $\mathrm{NH}_{4} \mathrm{NO}_{3}$ at one-fouth of MS level. Antioxidant enzyme activity was minimum in normal and healthy shoots. The activity increased with increase in the number of hyperhydric shoots.
\end{abstract}

Key words: Hyperhydricity, Carnation, Ammonium nitrate, Antioxidant enzyme, Shoot buds, Micropropagation

\section{INTRODUCTION}

Carnation is a top selling ornamental crop worldwide and an important target for breeding new varieties with improved agronomic traits. Carnation breeders seek novel varieties with superior horticultural characteristics to add up to the commercial value of the crop. Novelty is a major driving force for the ornamental industry. Long vase-life, colour variation, pest and disease resistance are all important features. However, a major limiting factor with traditional breeding techniques is the limited gene pool of carnation. Plant biotechnology can complement conventional breeding and expedite the crop improvement programmes. It offers an opportunity to exploit the cell, tissue, organ or entire organism by growing them in vitro and to genetically manipulate them to get desired compounds. In recent years, there has been an increased interest in in vitro techniques, which offers powerful tools for germplasm conservation and the mass multiplication of many commercially important plant species and valuable genotypes (Murch et al, 2000). Plant tissue and cell culture technologies have often been hailed as one of the most significant potential adjuncts for the expeditious release of improved cultivars, study and production of bioactive compounds, production of disease-free plants and genetic improvement. Thus, to constantly supply elite planting material and to meet the large scale demand, there is a need to establish mass production techniques and to improve the crop through the application of biotechnological methods.

There are several reports on micropropagation of Dianthus spp. using different explants such as shoot tips (Earle and Langhans 1975, Pareek et al. 2004,

\footnotetext{
*Corresponding Author: smita.purohit@iisuniv.ac.in
} 
Gatierrez-Miceli et al. 2010), stem pieces (Frey and Janick, 1991; Watad et al. 1996), leaf segments ( Jethwani and Kothari 1996, , Kantia and Kothari 2002), nodal segments (Van Altvorst et al. 1995, Pareek et al. 2004,), internodal segments (Thakur et al. 2002) and many more, but attempts to study the effect of mineral manupilation and antioxidant enzyme studies in relation to hyperhydricity in carnation culture are not been made. In vitro carnation culture is hampered by hyperhydricity. Hyperhydricity is a serious problem during in vitro culture of carnation. Hyperhydric malformations during in vitro propagation directly affect the production at commercial level (Rojas-Martinez et al, 2010). It is a morphological, physiological and anatomical disorder due to which the regenerated plantlets fail to survive when transferred to soil due to swelling, glassiness, yellowing and leaf curling of plantlets (Saher et al, 2004). Sutter and Langhans (1979) first reported the appearance of glassy and abnormal plants during in vitro culture of carnation. They reasoned the low survival rate to lack of epicuticular wax, inefficient vasculature and palisade tissue resulting in excessive desiccation. It is an abnormal state where stem and leaves are water soaked and translucent. Hyperhydric in vitro cultured plantlets do not survive when transferred to soil due to yellowing, swelling, glassiness and leaf curling of plantlets (Wetzstein and Sommer, 1982; Donelly and Materials and methods Vidaver, 1984). These morphological changes have been related to the low photosynthetic capacity of the leaves (Kevers et al, 1984; Paek et al, 1991). Approaches to overcome hyperhydricity include containers with good gaseous exchange, different concentrations of agar (Kevers and Gasper, 1986) the growth regulators BA, ABA (Kim et al, 1988), IAA (Li et al, 1997) and studying the ratio of nitrate to ammonium ions (Tsay et al, 1998). A common feature among the different ROS types is their capacity to cause oxidative damage to proteins, DNA, and lipids (Apel and Hirt, 2004). These cytotoxic properties of ROS explains the evolutionary complex array of nonenzymatic and enzymatic detoxification mechanism in plants. Several ROS are continously produced in plants as byproducts of aerobic metabolism (Apel and Hirt, 2004). To help protect against the destructive effects of ROS, aerobic organisms produce protective antioxidant enzymes such as catalase (CAT), superoxide dismutase (SOD). It was the evolution of these enzymes that made oxidative cellular metabolism possible. SOD is an enzyme that repairs cells and reduces the damage done to them by superoxide; the most common free radical in the body. It is widely recognized as an important ROS-scavenging enzyme in plants. It catalyzes dismutation of superoxide radicals to hydrogen peroxide and oxygen molecule and is the first line of defense against ROS, dismutating superoxide to $\mathrm{H} 2 \mathrm{O} 2$. CAT also subsequently detoxify $\mathrm{H} 2 \mathrm{O} 2$. Catalase is frequently used by cells to rapidly catalyze the decomposition of hydrogen peroxide into less reactive gaseous oxygen and water molecules. It forms the first line of defence against free radicals; therefore, their regulation depends mainly upon the oxidant status of the cell. Fatima et al 2009 reported that plant regeneration was influenced by plant growth regulators and similarly antioxidant enzyme activity has also marked effect on the various stages of growth and development. The objective of this work is to study the activities and behaviour of SOD and catalase enzymes at various levels of ammonium nitrate supplemented in MS medium and effect of hyperhydricity on the activity of these enzyme systems.

\section{MATERIALS AND METHODS}

Establishment of aseptic seedlings and explant preparation 
Seeds of $D$. caryophyllus were surface sterilized with $0.1 \%(\mathrm{w} / \mathrm{v})$ mercuric chloride for 3 minutes followed by four washes with sterile distilled water and germinated on half strength MS (Murashige and Skoog, 1962) medium. Nodal segments of $0.5 \mathrm{~mm}$ were aseptically dissected out from 21 days old seedlings and cultured on solid MS medium containing $2.2 \mu \mathrm{M}$ BAP $+2.7 \mu \mathrm{M}$ NAA supplemented with $3 \%(\mathrm{w} / \mathrm{v})$ sucrose and $1 \%(\mathrm{w} / \mathrm{v})$ agar with $\mathrm{pH} 5.8 \pm 0.01$ for shoot induction. The cultures were incubated at 16 $\mathrm{h}$ photoperiod at $26 \pm 1^{\circ} \mathrm{C}$.

\section{Culture media}

The nodal explants were inoculated on the MS medium supplemented with $2.2 \mu \mathrm{M}$ $\mathrm{BAP}+2.7 \mu \mathrm{M}$ NAA and sucrose $3 \%(\mathrm{w} / \mathrm{v})$. This was considered to be control induction medium having $20.61 * \mathrm{mM}$ of $\mathrm{NH} 4 \mathrm{NO} 3$ already present as a macronutrient in MS basal medium. The levels of ammonium nitrate $(0,5.15,10.3,20.61 *, 41.20 \mathrm{mM})$ were varied as $0,5.15$ (one fourth), 10.3 (half), 20.61 (control, having normal calcium concentration in MS basal medium), $41.20 \mathrm{mM}$. Five flasks ( $100 \mathrm{ml}$ 'Erlenmeyer' with $40 \mathrm{ml}$ medium in each) were prepared for each treatment having three explants per flask. Percentage response was calculated by dividing the total number of responding explants by total number of explants inoculated. Shoots buds induced from the explant were excised after 4 weeks and subcultured on normal medium NM (MS medium supplemented with $2.2 \mu \mathrm{M}$ BAP + $2.7 \mu \mathrm{M}$ NAA as present in normal MS medium) and on modified medium MM (MS medium supplemented with $2.2 \mu \mathrm{M}$ BAP + $2.7 \mu \mathrm{M}$ NAA and varied levels of ammonium nitrate: $0,5.15,10.3,20.61^{*}$, $41.20 \mathrm{mM} \mathrm{mM})$. Weekly observations were recorded for 4 weeks.

Shoot buds upto or more than $1 \mathrm{~cm}$ were taken into account and the number was counted manually for each treatment at the end of 4 weeks. Physiological characterization such as estimation of pigment concentration was determined in 4 weeks old culture and peroxidise enzyme activity was determined in 3 weeks and 5 weeks old cultures.

\section{Antioxidant enzyme activity}

Antioxidant enzyme activities were determined in the period 4 weeks of treatment.

\section{Extraction for assessment of enzyme activity}

One gram of fresh tissue (regenerated shoots) after three and five weeks of culture was ground by pre-chilled mortar and pestle with $0.05 \mathrm{M}$ potassium phosphate buffer $(\mathrm{pH}$ 7.0). The homogenate was centrifuged for 20 min at $5000 \mathrm{rpm}$. After centrifugation, the pellet was discarded and supernatant was mixed with cold acetone to a final concentration of $70 \%$ and centrifuged at $5000 \mathrm{rpm}$ for $10 \mathrm{~min}$ and the supernatant was used for enzyme assay.

\section{Determination of enzyme activities}

The peroxidase activity was assayed by Guaiacol-H2O2 method (Racusen and Foote, 1965). The reaction mixture was made by mixing $0.2 \mathrm{ml}$ enzyme extract, $1 \mathrm{ml}$ of $1 \%$ Guaioacol, $0.2 \mathrm{ml}$ of $50 \mathrm{mM} \mathrm{H} 2 \mathrm{O} 2$. Peroxidase activity was determined spectrophotometrically by monitoring the formation of tetraguaiacol at $470 \mathrm{~nm}$ after every 15 seconds. One unit of peroxidase activity corresponds to the levels of enzyme activity were expressed as moles of $\mathrm{H} 2 \mathrm{O} 2$ destroyed $/ \mathrm{min} / \mathrm{mg}$ protein.

Superoxide dismutase (EC 1.15.1.1) activity was assayed by monitoring the inhibition of photochemical reduction of nitro blue tetrazolium (NBT) according to the method of Beyer and Fridovich (1987). Leaves were homogenized in $1 \mathrm{ml}$ cold $100 \mathrm{mM} \mathrm{K}$ phosphate buffer $(\mathrm{pH}$ 7.8) containing 0.1 
$\mathrm{mM}$ ethylenediamine tetraacetic acid (EDTA), 1\% (w/v) polyvinyl-pyrrolidone (PVP) and $0.5 \%(\mathrm{v} / \mathrm{v})$ Triton X-100. One unit of SOD activity was defined as the amount of enzyme required to cause $50 \%$ inhibition of the reduction of NBT as monitored at $560 \mathrm{~nm}$.

Catalase (EC 1.11.1.6) activity was determined by following the consumption of $\mathrm{H} 2 \mathrm{O} 2$ (extinction coefficient, $39.4 \mathrm{mM}-1$ $\mathrm{cm}-1)$ at $240 \mathrm{~nm}$ for $3 \mathrm{~min}$ (Aebi, 1974).

\section{Rooting and acclimatization}

Shoots upto $2 \mathrm{~cm}$ and more in length were excised and transferred on to rooting medium consisting of full strength MS medium without any growth regulators. Plantlets with well-developed shoot and root systems were carefully taken out and washed with tap water to remove agar. These plantlets were then transferred to earthen pots containing garden soil and organic manure (1:1). Humidity was maintained initially by covering the pots with polythene bags. The experiment was repeated three times.

\section{RESULTS AND DISCUSSION}

Nodal segments were cultured on MS medium supplemented with BAP (0.5 mg l1) + NAA (0.5 mg 1-1) and different levels of NH4NO3 $\left(0,5.15,10.3,20.61^{*}, 41.2\right.$ $\mathrm{mM}$ ) (Table 1, Fig. 1a-d). NH4NO3 supplies nitrogen both in oxidized and reduced form. Shoot buds induced in the absence of NH4NO3 were weak and abnormal which could not form healthy shoots on subculture on proliferation medium. MS level of NH4NO3 (20.61 mM) was found to be optimal for induction and proliferation of shoots, but about $50 \%$ of the total shoots were hyperhydric. Reducing the level of NH4NO3 to one-fourth of the normal MS level i.e. $5.15 \mathrm{mM}$ resulted in the formation of 9-10 healthy shoots per explants (Fig. 1). No hyperhydricity was witnessed at this level of ammonium nitrate. The number of shoot buds induced from the explants was comparable to the control cultures but no hyperhydric shoot formation accompanied the normal shoot morphogenesis therefore hyperhydricity was controlled with $100 \%$ efficiency. Increasing the levels of ammonium nitrate up to $41.3 \mathrm{mM}$ did not show any response at induction as well as proliferation stages. Thus, $5.15 \mathrm{mM}$ of NH4NO3 was considered optimum for Dianthus cultures both in terms of morphogenic competence as well as controlling hyperhydricity.

Table 1. Effect of $\mathrm{NH}_{4} \mathrm{NO}_{3}$ on shoot bud induction and proliferation from nodal explants of Dianthus caryophyllus cultured on MS medium supplemented with BAP $\left(0.5 \mathrm{mg} \mathrm{l}^{-1}\right)$ and NAA $(0.5$ $\left.\mathrm{mg} \mathrm{l}^{-1}\right)$. Culture Period: 8 weeks

\begin{tabular}{|c|c|c|c|}
\hline $\begin{array}{c}\mathrm{NH}_{4} \mathrm{~N} \\
\mathrm{O}_{3} \text { in } \\
\text { inducti } \\
\text { on } \\
\text { mediu } \\
\text { m } \\
(\mathrm{mM})\end{array}$ & $\begin{array}{c}\begin{array}{c}\text { No. of shoot } \\
\text { buds/explan } \\
\mathbf{t}\end{array} \\
\text { Mean } \pm \text { S.D. }\end{array}$ & $\begin{array}{c}\mathrm{NH}_{4} \mathrm{NO}_{3} \\
\text { in } \\
\text { proliferati } \\
\text { on } \\
\text { medium } \\
(\mathrm{mM})\end{array}$ & $\begin{array}{c}\text { No. of } \\
\text { shoots/exp } \\
\text { lant } \\
\text { Mean } \pm \\
\text { S.D. }\end{array}$ \\
\hline 0 & $2.5 \pm 1.1$ & $\begin{array}{c}0 \\
20.61 *\end{array}$ & $\begin{array}{l}1.6 \pm 0.7 \\
1.7 \pm 0.8\end{array}$ \\
\hline 5.15 & $5.2 \pm 1.1$ & $\begin{array}{c}5.15 \\
20.61 *\end{array}$ & $\begin{array}{l}\mathbf{9 . 8} \pm \mathbf{0 . 6} \\
7.4 \pm 0.5\end{array}$ \\
\hline 10.3 & $4.3 \pm 0.7$ & $\begin{array}{c}10.3 \\
20.61 *\end{array}$ & $\begin{array}{l}8.1 \pm 0.6 \\
7.7 \pm 0.5\end{array}$ \\
\hline $20.61 *$ & $4.2 \pm 1.3$ & $20.61 *$ & $9.4 \pm 1.3$ \\
\hline 41.20 & - & - & - \\
\hline
\end{tabular}

Plant species and cultivars are genetically specific to their nutrient requirements hence no universal medium has been devised for in vitro cultures (Saric et al, 1995). Success of micropropagation largely depends on the chemical composition of the culture medium (Niedz and Evens, 2007). An understanding of optimal nutrient concentration could lead to increased growth and could evoke morphogenesis in vitro more efficiently. 


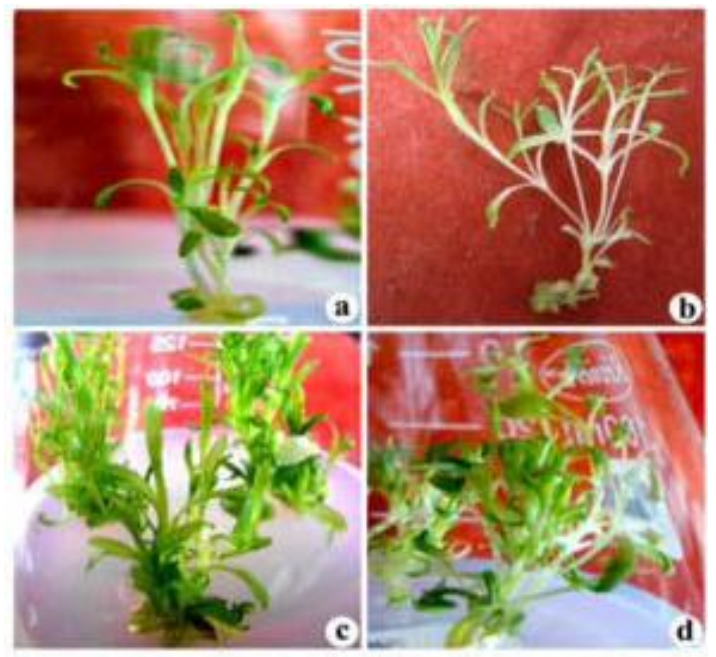

Fig. 1. Effect of of $\mathrm{NH}_{4} \mathrm{NO}_{3}$ on shoot bud induction from nodal explants of $D$. caryophyllus cultured on MS medium supplemented with BAP $\left(0.5 \mathrm{mg} \mathrm{l}^{-1}\right)$ and NAA $\left(0.5 \mathrm{mg} \mathrm{l}^{-1}\right)$
a. $\quad 5.15 \mathrm{mM} \mathrm{NH}_{4} \mathrm{NO}_{3}$
b. $* 20.6 \mathrm{mM} \mathrm{NH}_{4} \mathrm{NO}_{3}$

c-d. Effect of $\mathrm{NH}_{4} \mathrm{NO}_{3}$ on shoot proliferation from nodal explants of $D$. caryophyllus cultured on MS medium supplemented with BAP $\left(0.5 \mathrm{mg} \mathrm{l}^{-1}\right)$ and NAA (0.5 $\left.\mathrm{mg} \mathrm{l}^{-\mathbf{1}}\right)$
c. $5.15 \mathrm{mM} \mathrm{NH}_{4} \mathrm{NO}_{3}$ (induced on similar medium)
d. $* 20.6 \mathrm{mM} \mathrm{NH}_{4} \mathrm{NO}_{3}$ (induced on similar medium)

The nitrogen pool in a typical regeneration media usually comprises of the inorganic nitrate and ammonium. The compounds NH4NO3 and KNO3 are the source of inorganic nitrogen in the medium. In the present investigation, NH4NO3 at one-fouth of MS level was found to be beneficial for reducing the hyperhydricity of regenerated shoots whereas the number of shoots was comparable to the control cultures. The MS or higher levels of NH4NO3 were observed to suppress healthy morphogenesis and resulted in increased hyperhydricity. Several studies implicate elevated ammonium concentrations as a cause of hyperhydricity (Ivanova and Van Staden, 2008; Brand, 1993; Leonhardt and Kandeler, 1987). The inhibitory effect of $\mathrm{NH} 4+$ on regeneration has been ascribed to various aspects like lowering of $\mathrm{pH}$ of the medium which leads to increased acidity (Coussan and Van, 1993). Acidic medium produces a softer gel thus readily providing the stimulants of hyperhydricity to the regenerating plant such as NH4+, cytokinin and increased water potential of the medium (Modi et al, 2009). Similarly, Tsay and Drew (1998) reported that higher NO3-/NH4+ ratio in the medium prevented vitrification in carnation.

SOD, POD and CAT activity were significantly higher in hyperhydric tissue as compared to non-hyperhydric normal tissues (Fig. 2,3 \&4). The increase in SOD activity observed in hyperhydric tissue seemed to be mainly due to isoenzymes.

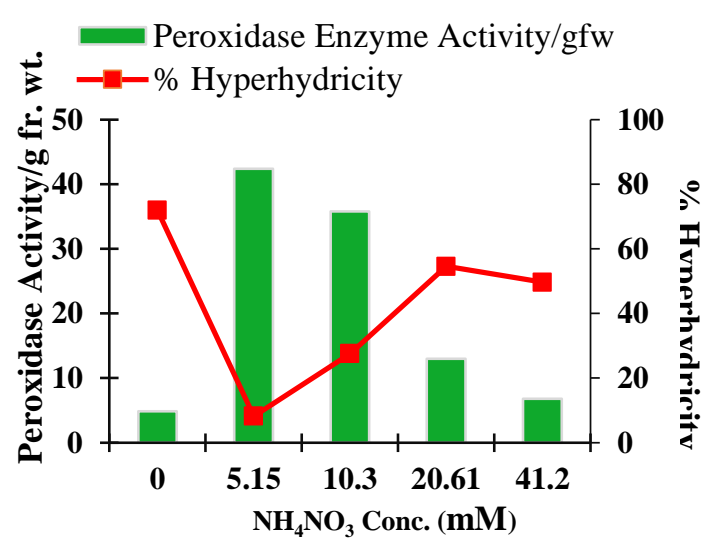

Fig. 2. Effect of $\mathrm{NH}_{4} \mathrm{NO}_{3}$ on peroxidase activity in D. caryophyllus

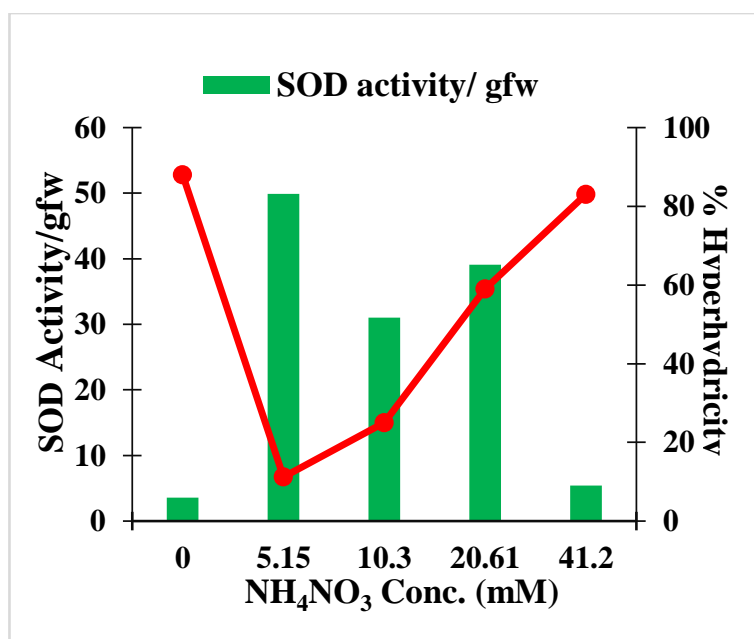

Fig. 3. Effect of $\mathrm{NH}_{4} \mathrm{NO}_{3}$ on SOD activity in $D$. caryophyllus 


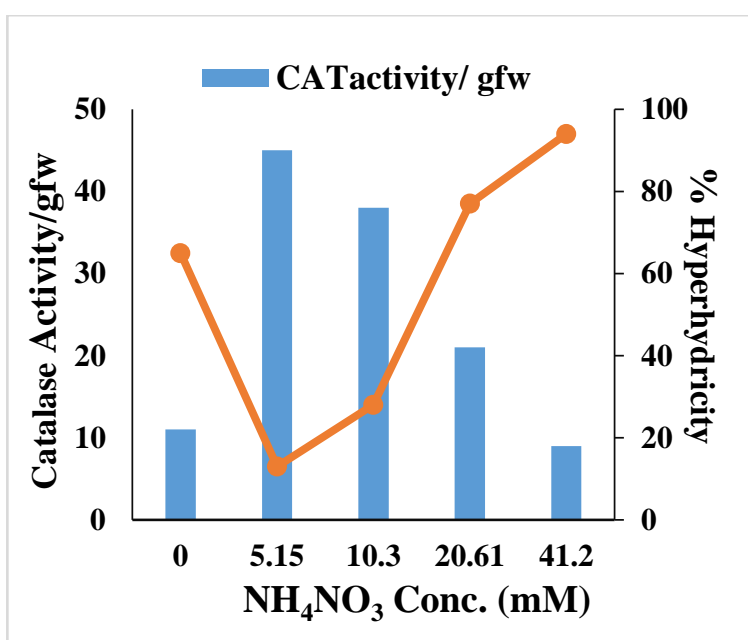

Fig. 4. Effect of $\mathrm{NH}_{4} \mathrm{NO}_{3}$ on catalase activity in $D$. caryophyllus

The oxidative stress is a key component of environmental stress, and increased antioxidant enzyme activity was correlated with increased protection from damage associated with oxidative stress. Our results showed that the CAT, SOD and PO activity increased significantly in treatments with more number of hyperhydric shoots. This implies that enhancement of SOD scavenge $\mathrm{O} 2 \bullet-$ radicals to protect from cellular oxidative damage. The oxidative stress is a key component of environmental stress, and increased SOD activity was correlated with increased protection from damage associated with oxidative stress. (Asada, 1999). However, Franck et al. (2004) argued for a stress response of the HS and suggests an alternative way of defense mechanisms in $\mathrm{HS}$, involving homeostatic regulation and controlled degradation processes to maintain integrity and vital functions of the cell.

\section{CONCLUSION}

To conclude, in the present investigation ammonium niitate $(5.15 \mathrm{mM})$ was found to be optimal for shoot morphogenesis in carnations. The problem of hyperhydricity witnessed in carnation tissue culture was rectified by 100 percent efficiency by reducing the levels of ammonium nitrate to one- fourth of the levels as found in MS medium. The enzyme activity of catalase, SOD and peroxidase was higher $\mathrm{n}$ the hyperhydric shoots as compared to activity of these enzymes in normal healthy shoots.

\section{ACKNOWLEDGEMENTS}

The authors acknowledge the financial assistance provided by Department of Science \& Technology (Rajasthan) under a minor project to Dr. Smita Purohit and scholarship provided by The IIS University, Jaipur, Rajasthan, to Ms. Meghana Agarwal.

\section{REFERENCES}

Aebi, H. 1974. Catalases. In: Bergmeyer, HU. (Ed.), Methods of Enzymatic Analysis, vol. 2. Academic Press, NY, pp. 673-684.

Apel, K. and Hirt, H. 2004. Reactive Oxygen Species: Metabolism, oxidative stress, and signal transduction. Annual Review of Plant Biology, 55:373-99.

Asada, K. 1999. The water-water cycle in chloroplasts: scavenging of active oxygens and dissipation of excess photons. Annual Review of Plant Physiology and Plant Molecular Biology, 50:601-639.

Beyer WF. and Fridovich, I. 1987. Assaying for superoxide disniutase activity: some large consequences of minor changes in conditions. Analytical Biochemistry, 161: 559-566.

Brand, MH. 1993. Agar and ammonium nitrate influence hyperhydricity, tissue nitrate and total nitrogen content of serviceberry (Amelanchier arborea) shoots in vitro. Plant Cell, Tissue and Organ Culture, 35: 203-209.

Cousson, A. and Van, KTT. 1993. Influence of ionic composition of the culture medium on de novo flower formation in tobacco thin cell layers. Canadian Journal of Botany, 71:506-511.

Donelly, VA. and Vidaver, W. 1984. Leaf anatomy of red raspberry transferred from culture to soil. Journal of the American Society for Horticultural Science, 109: 172-176. 
Earle, ED. and Langhans, RW. 1975. Carnation propagation from shoot tips cultured in liquid medium. Horticultural Science, 10: 608-610.

Franck, T., Kevers, C. and Gasper, T. 1995. Protective enzymatic systems against activated oxygen species compared in normal and hyperhydric shoots of Prunus avium L. raised in vitro. Plant Growth Regulators, 16:253-256.

Frey, L. and Janick, J. 1991. Organogenesis in carnation. Journal of the American Society for Horticultural Science, 116:1108-1112.

Gatierrez-Miceli, FA., Arias, L., JuarezRodriguez, N., Abud-Archila, M., Amaro-Reyes, A. and Dendooven, L. 2010. Optimization of growth regulators and silver nitrate for micropropagation of Dianthus caryophyllus L. with the aid of a response surface experimental design. In Vitro Cellular and Developmental Biology-Plant, 46: 57-63.

Ivanova, M. and van Staden, J. 2008. Effect of ammonium ions and cytokinins on hyperhydricity and multiplication rate of in vitro regenerated shoots of Aloe polyphylla. Plant Cell, Tissue and Organ Culture, 92:227-231.

Jethwani, V. and Kothari, SL. 1996. Phenylacetic acid induced organogenesis in cultured leaf segments of Dianthus chinensis. Plant Cell Reports, 15:869872.

Kantia, A. and Kothari, SL. 2002. High efficiency adventitious shoot bud formation and plant regeneration from leaf explants of Dianthus chinensis L. Scientia Horticulture, 96:205-212.

Kevers, C. and Gasper, T. 1986. Vitrification of carnation in vitro: change in water contents, extracellular space, air volume and ion levels. Physiologie végétale, 24:647-653.

Kevers, C., Coumans, M., Coumans-gilles, MF. and Gasper, T. 1984. Physiological and biochemical events leading to vitrification of plants cultured in vitro. Physiologia Plantarum, 61:69-74.
Kim, KW., Byun, MS. and Kang, MS. 1988. Effect of $\mathrm{ABA}$ and agar in preventing vitrification of carnation plantlets cultured in vitro. Journal of Korean Society of Horticulture Science, 29:208215.

Leonhardt, W. and Kandeler, R. 1987. Ethylene accumulation in culture vesselsa reason for vitrification?. Acta Horticulturae, 212:223-230.

Li, Y., Wang, L., Ye, M., Shen, D., Li, Y., Wang. LH., Ye, MM. and Shen, DL. 1997. The factors influencing vitrification of tissue-cultured carnation plantlets. Plant Physiology Communications, 33:256-258.

Modi, P., Sinha, A. and Kothari, SL. 2009. Reduction of hyperhydricity in micropropagated French Marigold (Tagetes patula L.) plants by modified medium parameters. Floriculture and Ornamental Biotechnology, 3:40-45.

Murashige, T. and Skoog, F. 1962. A revised medium for rapid growth and bioassays with tobacco tissue culture. Physiologia Plantarum, 15:473-497.

Murch, SJ., KrishnaRaj, S. and Saxena, PK. 2000. Phytomaceuticals: Mass production, standardization and conservation. Scientific Review of Alternative Medicine, 4:39-43.

Niedz, RP. and Evens, TJ. 2007. Regulating plant tissue growth by mineral nutrition. In Vitro Cellular and Developmental Biology-Plant, 43:370-381.

Paek, KY., Han, BH. and Choi, SL. 1991. Physiological, biochemical and morphological characteristics of vitrified shoots regenerated in vitro. Korean Journal of Plant Tissue Culture, 3:151162

Pareek, A., Kantia, A. and Kothari, SL. 2004. In vitro cloning of ornamental species of Dianthus. Indian Journal of Biotechnology, 3:263-266.

Racusen, D. and Foote, M. 1965. Protein synthesis in dark-grown bean leaves. Canadian Journal of Botany, 43:817-824. Rojas-Martínez, L., Visser, RGF., and De Klerk, GJ. 2010. The hyperhydricity 
syndrome: waterlogging of plant tissues as a major cause. Propagation of Ornamental Plants, 10:169-175.

Saher, S., Piqueras, A., Hellin, E. and Olmos, E. 2004. Hyperhydricity in micropropagted carnation shoots: the role of oxidative stress. Physiologia Plantarum, 120:152.

Saric, M., Mezei, S. and Ruzic, D. 1995. Genetic aspects of mineral nutrition of plants grown in vitro. Archives of Biological Sciences, 47:1-12.

Sutter, E. and Langerhans, LW. 1979. Epicuticular wax formation on carnation plantlets regenerated from shoot tip culture. Journal of the American Society for Horticultural Science, 104:493-496.

Thakur, M., Sharma, DR. and Sharma, SK. 2002. In vitro regeneration of carnation (Dianthus caryophyllus L.) plants resistant to culture filtrate of Fusarium oxysporum f.sp. dianthi. Plant Cell Reports, 20:825-828.

Tsay, H., Tsay, HS. and Drew, RA. 1998. Effect of medium compositions at different recultures on vitrification of carnation (Dianthus caryophyllus) in vitro shoot proliferation. Acta Horticulturae, 461:243-249.

van Altvorst, AC., Yancheva, S. and Dons, H. 1995. Cells within the nodal region of carnation shoots exhibits a high potential for adventitious shoot formation. Plant Cell, Tissue and Organ Culture, 40:151157.

Watad, AA., Ahroni, A., Shejtman, H., Nissim, A. and Vainstein. A. 1996. Adventitious shoot formation from carnation stem segments: a comparison of different culture procedures. Scientia Horticulture, 65:313-320.

Wetzstein, HY. and Sommer, HE. 1982. Leaf anatomy of tissue cultured Liquidambar stryraciflua during acclimatization. American Journal of Botany, 69:1579-1586. 